\title{
Hepatitis B virus promotes $\beta$-catenin-signalling and disassembly of adherens junctions in a Src kinase dependent fashion
}

\author{
Gesa von Olshausen ${ }^{1}$, Maria Quasdorff ${ }^{2,3}$, Romina Bester ${ }^{4}$, Silke Arzberger ${ }^{2,4}$, \\ Chunkyu Ko ${ }^{4}$, Maarten van de Klundert ${ }^{4}$, Ke Zhang ${ }^{4}$, Margarete Odenthal ${ }^{5,6}$, Marc \\ Ringelhan $^{4,7}$, Carien M. Niessen ${ }^{6,8,9}$ and Ulrike Protzer ${ }^{4,10}$ \\ ${ }^{1}$ Department of Internal Medicine I, University Hospital rechts der Isar, Technical University of Munich, Munich, Germany \\ ${ }^{2}$ Molecular Infectiology, Institute for Medical Micro biology, Immunology and Hygiene, University Hospital Cologne, Cologne, \\ Germany \\ ${ }^{3}$ Department of Gastroenterology and Hepatology, University Hospital Cologne, Cologne, Germany \\ ${ }^{4}$ Institute of Virology, Technical University of Munich/Helmholtz Zentrum München, Munich, Germany \\ ${ }^{5}$ Institute of Pathology, University Hospital Cologne, Cologne, Germany \\ ${ }^{6}$ Center for Molecular Medicine (CMMC), University of Cologne, Cologne, Germany \\ ${ }^{7}$ Department of Internal Medicine II, University Hospital rechts der Isar, Technical University of Munich, Munich, Germany \\ ${ }^{8}$ Department of Dermatology, University Hospital of Cologne, Cologne, Germany \\ ${ }^{9}$ Cologne Excellence Cluster on Cellular Stress Responses in Aging-Associated Diseases (CECAD), University of Cologne, \\ Cologne, Germany \\ ${ }^{10}$ German Center for Infection Research (DZIF), Munich Partner Site, Munich, Germany \\ Correspondence to: Ulrike Protzer, email: protzer@tum.de \\ Carien M. Niessen, email: carien.niessen@uni-koeln.de \\ Keywords: hepatitis B virus (HBV); hepatocellular carcinoma (HCC); $\beta$-catenin; Src kinase; E-cadherin \\ Received: April 10,2018 Accepted: August 27, $2018 \quad$ Published: September 21, 2018 \\ Copyright: von Olshausen et al. This is an open-access article distributed under the terms of the Creative Commons Attribution \\ License 3.0 (CC BY 3.0), which permits unrestricted use, distribution, and reproduction in any medium, provided the original author \\ and source are credited.
}

\section{ABSTRACT}

Hepatitis B virus (HBV) infection is a prominent cause of hepatocellular carcinoma (HCC) but the underlying molecular mechanisms are complex and multiple pathways have been proposed such as the activation of the Wnt-/ $\beta$-catenin-signalling and dysregulation of E-cadherin/ $\beta$-catenin adherens junctions. This study aimed to identify mechanisms of how HBV infection and replication as well as HBV $X$ protein (HBX) gene expression in the context of an HBV genome influence Wnt-/ $\beta$-cateninsignalling and formation of adherens junctions and to which extent HBx contributes to this.

Regulation of E-cadherin/ $\beta$-catenin junctions and $\beta$-catenin-signalling as well as the role of $\mathrm{HBx}$ were investigated using constructs transiently or stably inducing replication of $\mathrm{HBV}+/-\mathrm{HBX}$ in hepatoma cell lines. In addition, HCC and adjacent nontumorous tissue samples from HBV-infected HCC patients and drug interference in HBV-infected cells were studied.

Although HBV did not alter overall expression levels of E-cadherin or $\beta$-catenin, it diminished their cell surface localization resulting in nuclear translocation of $\beta$-catenin and activation of its target genes. In addition, HBV gene expression increased the amount of phosphorylated c-Src kinase. Treatment with Src kinase inhibitor Dasatinib reduced HBV replication, prevented adherens junction disassembly and reduced $\beta$-catenin-signalling, while Sorafenib only did so in cells with mutated $\beta$-catenin. Interestingly, none of the HBV induced alterations required $\mathrm{HBX}$. 


\section{Thus, HBV stimulated $\beta$-catenin-signalling and induced disassembly of adherens junctions independently of $\mathrm{HBx}$ through Src kinase activation. These pathways may contribute to hepatocellular carcinogenesis and seem to be more efficiently inhibited by Dasatinib than by Sorafenib.}

\section{INTRODUCTION}

With over 800000 deaths in 2015, liver cancer represents the fourth leading cause of cancer death in the world [1]. Hepatocellular carcinoma (HCC) is the dominant histologic type of liver cancer in most countries accounting for approximately $80 \%$ of total cases [2]. Hepatitis B virus (HBV) is one of the most common chronic infections worldwide with an estimated 257 million chronically infected subjects (WHO 2017). It is the leading cause for hepatocellular carcinoma and accounted for $>880.000$ deaths (WHO 2017) and at least 265000 liver cancer deaths in 2015 [1]. A plethora of different mechanisms through which HBV contributes to HCC initiation and progression have been described (summarized in [3]) and are subject of current investigations.

Hepatitis B virus (HBV) is the prototypic member of the hepadnaviridae, a family of small enveloped DNAcontaining viruses. Because of their replication via reverse transcription of a pregenomic RNA (pgRNA), they are classified as pararetroviruses. HBV contains four open reading frames encoding the structural capsid, envelope proteins, the viral polymerase that serves as reverse transcriptase and the non-structural HBV X protein ( $\mathrm{HBx})$. Infection with $\mathrm{HBV}$ induces Src tyrosine kinase activity to promote its replication on the transcriptional and posttranscriptional level $[4,5]$.

The role of HBV in tumor formation is complex and likely involves both direct and indirect mechanisms $[3,6,7]$. Integration of HBV-DNA into the host genome may cause mutations and/or activation of diverse cancer-related genes, which subsequently drive clonal hepatocyte expansion at an early stage of HCC development [8]. Moreover, chronic liver inflammation and hepatic regeneration induced by cellular immune responses may also favour the accumulation of genetic alterations in infected hepatocytes [9]. Over the last years a growing body of evidence suggests that in addition to these mentioned well-established mechanisms pleiotropic effects of viral HBV proteins also contribute to $\mathrm{HCC}$ initiation and/or progression [10]. In this context, the HBV-encoded envelope and HBx proteins are reported to play an important role via distinct and non-overlapping pathways [3]. PreS/S mutants of HBV large surface antigens are suggested to induce endoplasmic reticulum stress via an unfolded protein response thereby leading to oxidative stressinduced DNA damage/mutation and activation of cell proliferation-related signals $[11,12]$. In addition, numerous functions have been attributed to HBx: e.g. regulation of cytoplasmic calcium levels [13, 14], disruption of adherens junctions [15], induction of a migratory phenotype [16], activation of $\beta$-cateninsignalling [17] and recruiting the Smc5/6 complex for ubiquitination inducing its proteasomal degradation and thus influencing HBV gene expression [18]. HBx induced Smc5/6 degradation, however, may also influence cell division and DNA repair [3].

The canonical Wnt-signalling pathway determines cell fate in many tissues and organs [19, 20], with $\beta$-catenin as the key downstream signal transducer. Wnt binding to its receptor results in stabilization of cytosolic $\beta$-catenin and subsequent translocation to the nucleus where it interacts with DNA-binding proteins of the Tcf/ LEF (T cell factor/lymphocyte enhancer factor) family $[21,22]$ to transcriptionally activate downstream targets, such as e.g. c-myc and glutamine synthase (GS) [23-25]. Dysregulation of Wnt/ $\beta$-catenin-signalling is observed in a number of cancers, including HCC [26-28]. In mouse models, it has been shown that increased $\beta$-cateninsignalling directly contributes to $\mathrm{HCC}$ progression [29]. Next to its role in signalling, $\beta$-catenin also binds to the cytoplasmic domain of the cell adhesion protein E-cadherin and interacts with the actin binding protein $\alpha$-catenin providing the $\mathrm{E}$-cadherin $/ \beta$-catenin complex with a dynamic link to the cytoskeleton. This cadherin/ catenin complex forms the molecular backbone of the intercellular adherens junctions [30].

Loss of E-cadherin is a characteristic feature of epithelial to mesenchymal transition (EMT) and observed in a broad spectrum of human carcinomas [31-33]. This EMT induced E-cadherin loss is often accompanied by $\beta$-catenin nuclear translocation and signalling activation. In addition, it was shown that E-cadherin loss directly contributes not only to tumor invasion but also to tumor initiation [34]. Changes in E-cadherin expression or localization are also observed in human HCCs [35, 36] and in HCC mouse models [37]. However, in some HCC patients the frequently observed activation of $\beta$-catenin seemed to be independent of E-cadherin loss, suggesting additional mechanisms for $\beta$-catenin activation [35].

In the present study we investigated whether and how HBV stimulates $\beta$-catenin-signalling and disassembly of adherens junctions. We describe that both require c-Src kinase activation but not the viral transactivator HBx. Furthermore, we demonstrate that inhibition of Src kinase activity by Dasatinib restored adherens junctions, reduced $\beta$-catenin-signalling and repressed HBV replication. 


\section{RESULTS}

\section{HBV does not alter protein levels of E-cadherin/ $\beta$-catenin}

To examine whether HBV replication and expression of $\mathrm{HBx}$ under its endogenous promoter influence E-cadherin or $\beta$-catenin protein levels, we performed qPCR and Western blot analysis in HepG2 cell lines stably transfected with replication competent HBV overlength genome $\mathrm{H} 1.3$ or $\mathrm{H} 1.3 \mathrm{x}^{-}$. Under conditions that have been shown to promote differentiation [38] such as plating onto a collagen matrix and medium containing dexamethasone, DMSO and low FCS, cells were allowed to differentiate for different times. In both cell lines, pgRNA (Figure 1a) and HBV replication levels (data not shown) increased over time during differentiation as previously described [39]. Western blot analysis revealed no change in either E-cadherin or $\beta$-catenin levels whereas $\mathrm{HBV}$ core protein and HBeAg levels steadily increased (Figure 1b). Investigating human tumor and peritumor liver tissue from individuals with and without HBV infection, numeric differences at E-cadherin (Figure 1c) and $\beta$-catenin (Figure 1d) mRNA expression levels could be detected. Nevertheless, there was no clear correlation with pgRNA in HBV infected patients (Figure 1c and 1d, left panel). In HBV negative patients, there was a trend to higher E-cadherin and lower $\beta$-catenin mRNA expression levels (Figure 1c and 1d, right panel). However, according to the results of the hepatoma cell lines' western blot, neither a difference in E-cadherin or $\beta$-catenin expression nor a correlation with HBV core expression levels could be detected when peritumor and tumor liver tissue from individuals with HBV infection were analyzed (Figure 1e, left panel). Moreover, no obvious difference between HBV-positive (Figure 1e, left panel) and HBV-negative patients was observed (Figure 1e, right panel). In fact, the most striking observation was the high inter-individual heterogeneity of E-cadherin and $\beta$-catenin protein levels. These data indicate that HBV does not directly regulate either E-cadherin or $\beta$-catenin expression levels, regardless of HBx expression.

\section{HBV alters E-cadherin/ $\beta$-catenin localization}

Since HBV did not change overall E-cadherin or $\beta$-catenin protein levels we next investigated whether it affects E-cadherin/ $\beta$-catenin localization. Cell surface biotinylation assays revealed diminished surface levels of E-cadherin and $\beta$-catenin in both HepG2 cells replicating HBV wildtype (H1.3) and $\mathrm{x}$-deficient HBV (H1.3x-) compared to the parental control cell line (Figure 2a). To examine the subcellular localization of E-cadherin/ $\beta$ catenin, immunofluorescence analysis was performed. Less E-cadherin was located to sites of cell-cell contacts in $\mathrm{HepG} 2-\mathrm{H} 1.3$ and $-\mathrm{H} 1.3 \mathrm{x}^{-}$cells when compared to control cells (Figure 2b). Instead, a punctuated pattern was observed in the cytoplasm, suggesting that E-cadherin was internalized or not efficiently transported back to the cell surface upon HBV replication. Similarly, an overall decrease in cell surface localization of $\beta$-catenin was observed in cells replicating HBV accompanied by a strong increase in both cytosolic and nuclear staining of $\beta$-catenin (Figure 2c). Interestingly, neither loss of cell surface localization of E-cadherin/ $\beta$-catenin nor $\beta$-catenin translocation did depend on the presence of HBx (Figure $2 a+2 b+2 c)$. Hence, these results demonstrate that HBV results in nuclear $\beta$-catenin translocation and reduces adherens junctions independently of HBx expression.

\section{HBV enhances $\beta$-catenin-signalling}

The strong increase in cytosolic and nuclear $\beta$-catenin levels indicated that HBV may activate $\beta$-catenin-signalling. Tcf/LEF dependent luciferase reporter assays revealed a 3.8-fold enhanced $\beta$-cateninsignalling in both HepG2-H1.3 and HepG2-H1.3 $\mathrm{x}^{-}$cell lines when compared to parental HepG2 cells (Figure $3 a)$. HepG2 cells express a stabilized mutant $\beta$-catenin, $\mathrm{S} 33 \mathrm{~A}$, and thus are already more active $[17,24]$, suggesting perhaps that HBV simply enhanced this activity. To furthermore exclude a clonal cell selection we also repeated the analysis in Huh7 cells, which express wildtype $\beta$-catenin, to evaluate whether HBV is also initiating $\beta$-catenin-signalling. After transient transfection with $\mathrm{H} 1.3$ and $\mathrm{H} 1.3 \mathrm{x}^{-}$expressing plasmids, HBV replication in Huh7 cells was confirmed by measuring progeny virus release (Figure 3b). A 9-fold increase in Tcf/LEF reporter activity was found in both transiently transfected Huh 7 cell lines (Figure 3b). Importantly, HBV induced the expression of the $\beta$-catenin target gene c-myc (Figure $3 \mathrm{c}$ ), further confirming active $\beta$-catenin-signalling in these cells. These results demonstrate that HBV initiates and enhances $\beta$-catenin-signalling in an HBx independent fashion.

\section{$\mathrm{HBV}$ replication and $\beta$-catenin-signalling are regulated by Src kinase activity}

To dissect the mechanism by which HBV leads to increased $\beta$-catenin-signalling we analyzed c-Src kinase activity, which has been shown to promote reverse transcription and DNA replication in HBV infection [4]. Western blot analysis showed a pronounced increase of activated, phospo-Tyr416-Src levels in HBV-replicating HepG2 as compared to control cells (Figure 4a). Next, we investigated whether HBV replication itself leads to an upregulation of phospo-Tyr416-Src levels. Blocking HBV replication by the reverse transcriptase inhibitor Entecavir in HepG2H1.3 cells (Figure 4b) or in HepG2.2.15 cells (data not sown) did neither show an effect on total nor on phospo-Tyr416-Src levels. 


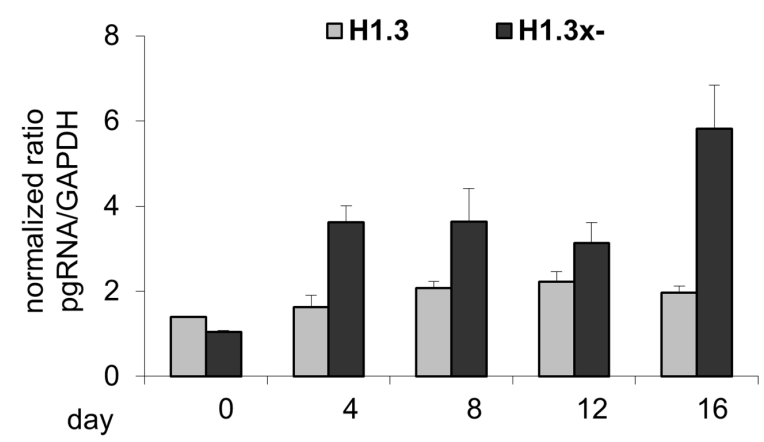

b

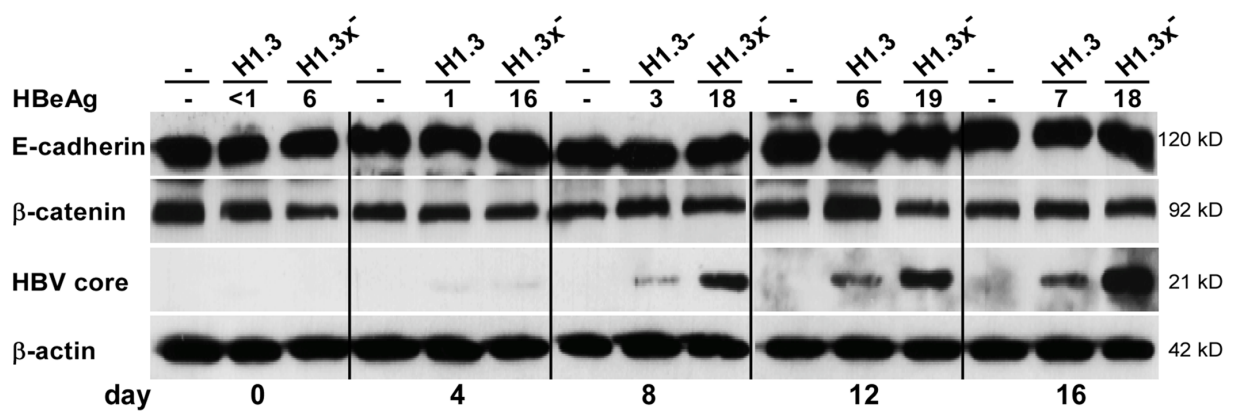

C

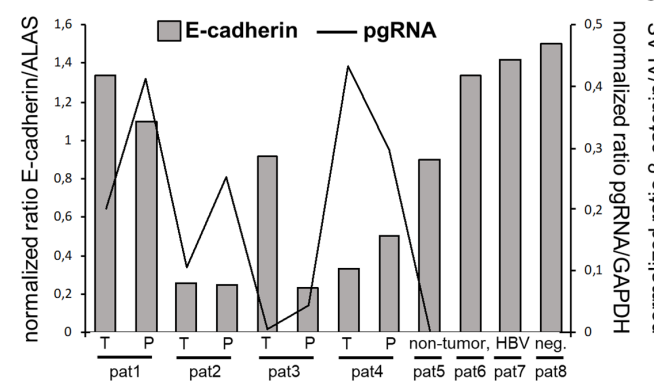

d

e

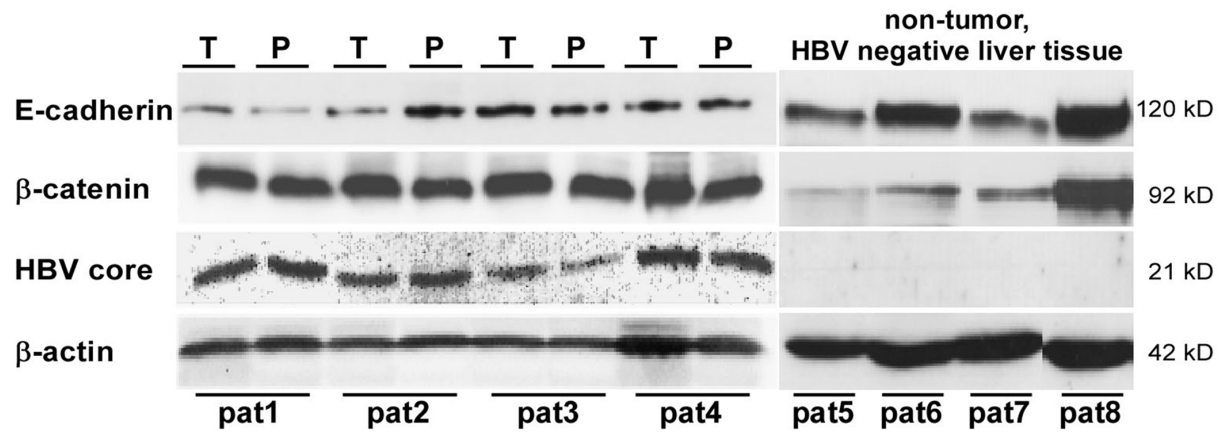

Figure 1: Total protein levels of E-cadherin/ $\beta$-catenin in HBV-replicating hepatoma cells and mRNA expression/ total protein levels of E-cadherin/ $\beta$-catenin in human liver tissue (HBV-infected and HBV-negative). (a) HBV pgRNA (quantified by real-time PCR) in stably transfected HBV-producing HepG2 cell lines (H1.3 and H1.3 $\mathrm{x}^{-}$) in a time course experiment. Day 0 was defined as day when cells were $80-90 \%$ confluent (here: 2 days post plating). mRNA and proteins were extracted at day $0,4,8,12$ and 16. Normalized expression ratios relative to housekeeping gene GAPDH are given. The assays were performed in independent triplicates, means + SD are shown. (b) Western blot analysis of E-cadherin, $\beta$-catenin and HBV core protein (same time course experiment) in parental (-) and stably transfected HBV-producing HepG2 cells (H1.3 and $\left.\mathrm{H} 1.3 \mathrm{x}^{-}\right)$. HBeAg levels in cell culture supernatants are given in ng ml-1. $\beta$-actin was stained as loading control. (c) E-cadherin mRNA and (d) $\beta$-catenin mRNA as well as HBV pgRNA were quantified by real-time PCR in liver tissue of paired tumor (T)/peritumur (P) tissue samples of four HBV-infected human livers with HCC (pat1-pat4) and four non-tumor, HBV-negative livers (pat5-pat8). Normalized expression ratios relative to house keeping gene ALAS and GAPDH are given. (e) Western blot analysis of E-cadherin, $\beta$-catenin and HBV core protein of the same liver tissue lysates of paired tumour (T)/peritumour (P) tissue samples of four HBV-infected human livers with HCC (pat1-pat4) and four non-tumor, HBV-negative livers (pat5-pat8). $\beta$-actin was stained as loading control. 
a

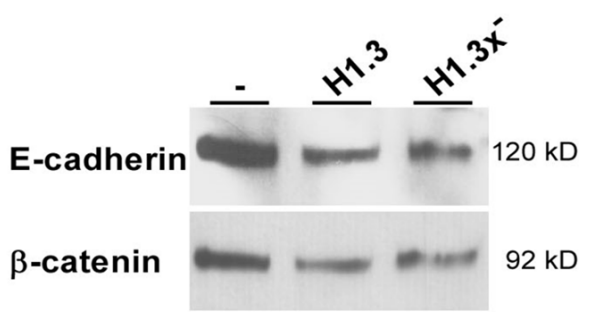

b
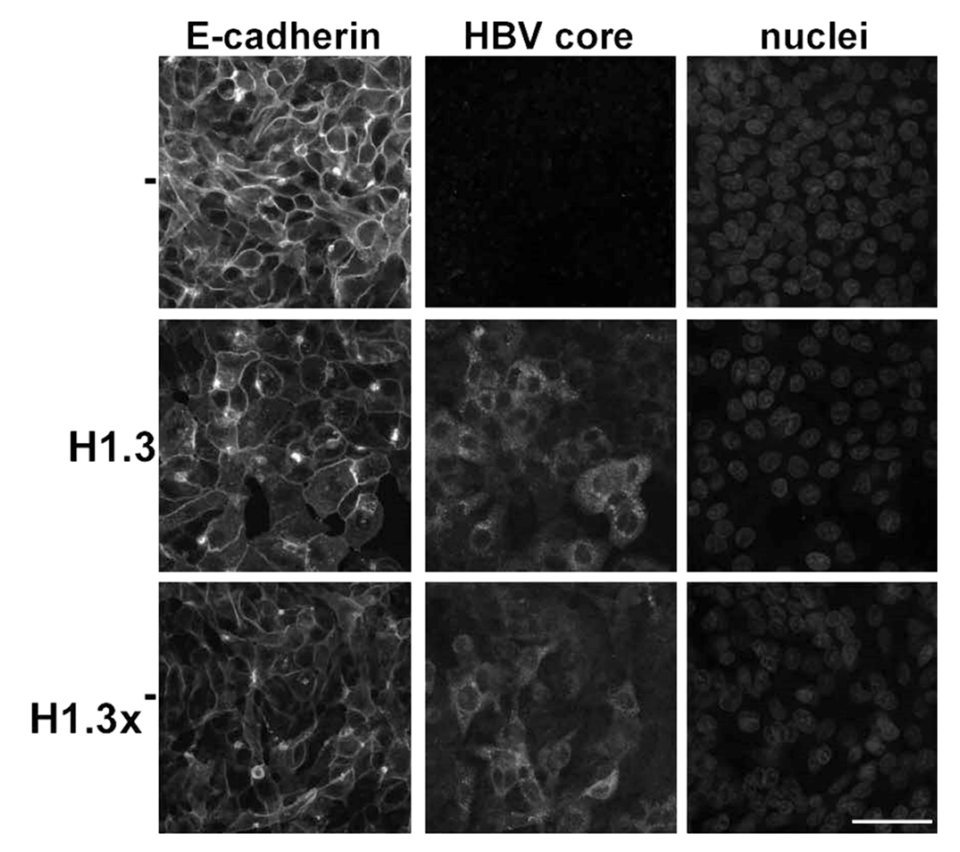

C

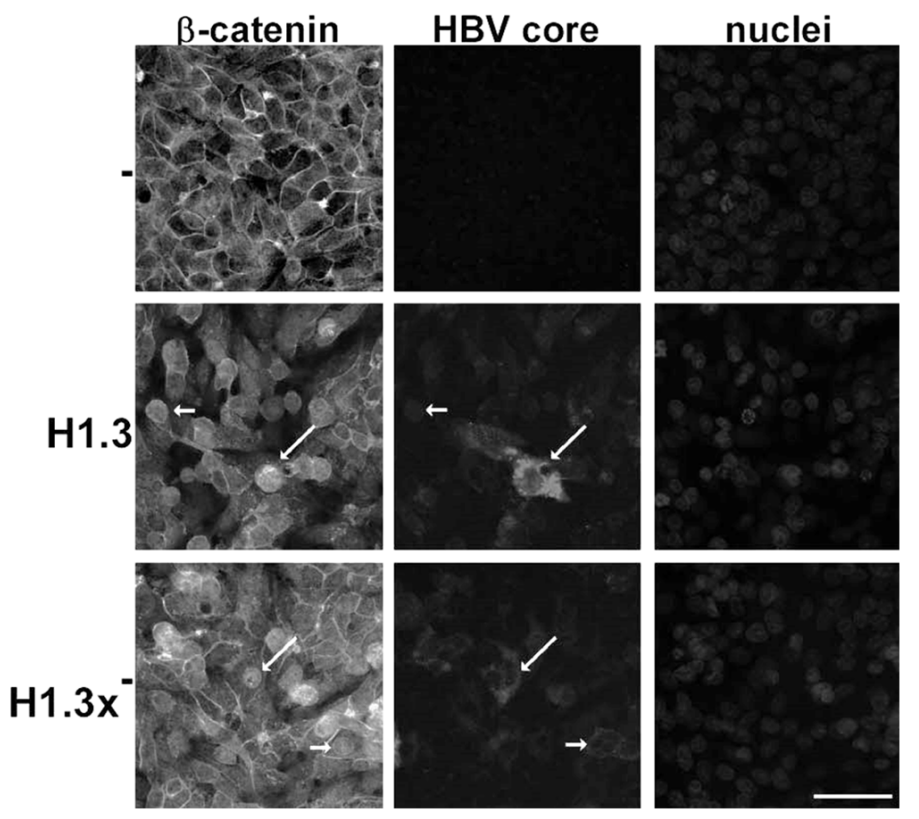

Figure 2: Distribution of E-cadherin/ $\beta$-catenin in HBV-replicating hepatoma cells. (a) Membrane fractions (isolated via a cell surface biotinylation assay) of E-cadherin and $\beta$-catenin in HBV-producing (H1.3 + H1.3x-) compared to parental (-) HepG2 cells were analyzed by Western blot. Immunoflourescence staining of (b) E-cadherin and (c) $\beta$-catenin (nuclear translocation indicated by arrows) in parental (-) and HBV-producing (H1.3 + H1.3x-) HepG2 cells. Co-staining of HBV core protein (indicated by arrows) and nuclei. Scale bars indicate $40 \mu \mathrm{m}$. 
To examine if increased c-Src kinase activity is indeed involved in $\mathrm{HBV}$ replication, activation of $\beta$-catenin-signalling and disassembly of adherens junctions, we treated HBV-replicating Huh7 cells with Dasatinib. This ATP-competitive tyrosine kinase inhibitor inhibits all members of Src family, including c-Src, Lck, Fyn and Yes [40, 41]. Dasatinib treatment reduced Tcf/LEF dependent $\beta$-catenin-signalling in Huh7 cells replicating $\mathrm{HBV}(\mathrm{H} 1.3)$ or $\mathrm{x}$-deficient $\mathrm{HBV}\left(\mathrm{H} 1.3 \mathrm{x}^{-}\right)$ to levels observed in parental control cells (Figure 5a, grey bars). In addition, Dasatinib reduced HBV gene expression 7- to 8-fold as demonstrated by progeny virus release (Figure 5a, white bars) and HBeAg ELISA (data not shown). Moreover, immunofluorescence analysis of HBV-replicating Huh7 cells treated with Dasatinib showed that inhibition of Src phosphorylation also prevented
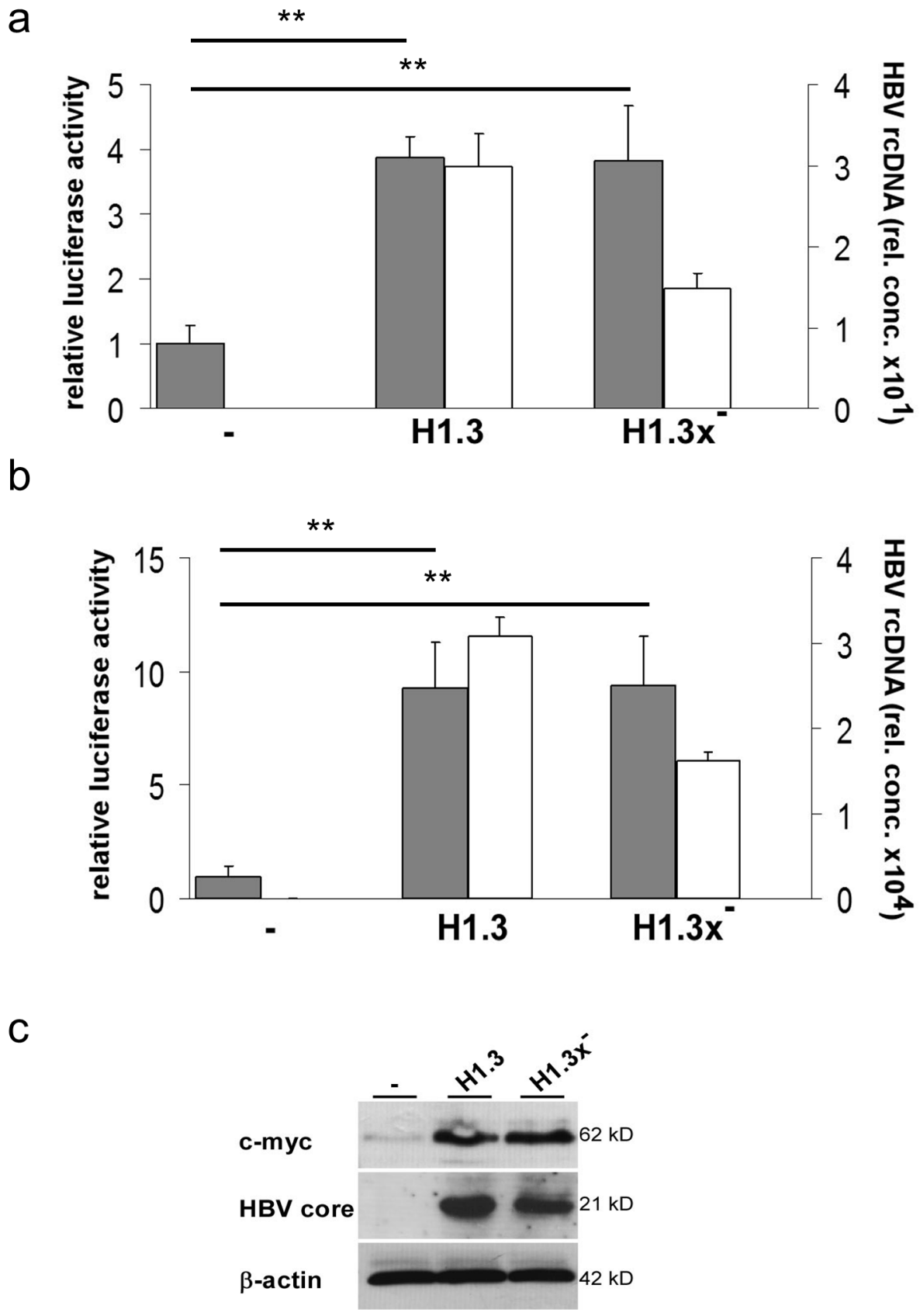

Figure 3: Tcf/LEF dependent $\beta$-catenin-signalling in HBV-replicating hepatoma cells. Relative luciferase activity indicates the level of Tcf/LEF dependent $\beta$-catenin-signalling (grey bars) in parental (-) or H1.3x or H1.3x- (a) replicating HepG2 and (b) transfected Huh7 cells. Ratios in parental cells were set to 1 . Active viral replication was determined by measuring HBV rcDNA (white bars) levels in supernatants of HBV-producing cells. The assays were performed in independent triplicates, means $+\mathrm{SD}$ are shown. ${ }^{* *} \mathrm{p}<0.01$ vs parental cells, t-test. (c) c-myc and HBV core protein levels were subjected to Western blot analysis in parental (-) compared to HBV-replicating $\left(\mathrm{H} 1.3+\mathrm{H} 1.3 \mathrm{x}^{-}\right) \mathrm{HepG} 2$ cells. 
the disassembly of adherens junctions induced by HBV (Figure 5b).

Since Dasatinib treatment reduced Tcf/LEF dependent $\beta$-catenin-signalling in $\mathrm{HBV}$ transfected cells, we next investigated the effects of Dasatinib treatment on HBV replication and $\beta$-catenin target gene mRNA glutamine synthetase (GS) expression levels in HBV infected HepG2-NTCP and Huh7.5-NTCP cells, which are permissive to $\mathrm{HBV}$ and allow investigating the full viral life cycle [42]. In addition, we compared the effects of Dasatinib treatment to that of Sorafenib, a tyrosine kinase inhibitor that inhibits Raf kinase and the vascular endothelial growth factor receptor intracellular kinase pathway [43] and is the recommended treatment for advanced HCC (Grade 1B) [44]. In HBV infected HepG2-NTCP cells that carry S33A mutated $\beta$-catenin, HBV pgRNA as well as GS expression levels were significantly reduced to the same extend by both drugs (Figure 5c). In HBV infected Huh7.5-NTCP cells that carry wildtype $\beta$-catenin in contrast, HBV pgRNA as well as GS expression levels were reduced by Dasatinib but not by Sorafenib (Figure 5d). These results strongly indicate a role of Src kinase not only in HBV infection but also in HBV induced $\beta$-catenin translocation and signalling that maybe therapeutically targeted by tyrosine-kinase inhibitor treatment.

\section{DISCUSSION}

In this study we identify a link between HBV, increased Src kinase activity, adherens junction instability and enhanced $\beta$-catenin-signalling. We show that HBV induces phosphorylation of c-Src kinase leading to activation of HBV transcription and replication as well as $\beta$-catenin-signalling and disassembly of adherens junctions independent of the viral transactivator $\mathrm{HBx}$. These processes can be modified by the tyrosine kinase inhibitors Dasatinib and Sorafenib. Our results suggest that increased $\beta$-catenin-signalling in the liver is one route by which HBV contributes to HCC development.

A previous report showed that HBx overexpression leads to a downregulation of E-cadherin in cell culture

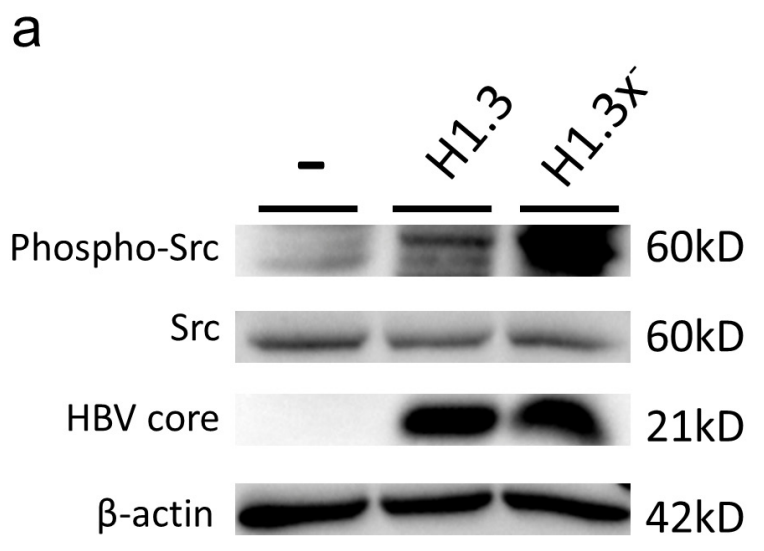

b

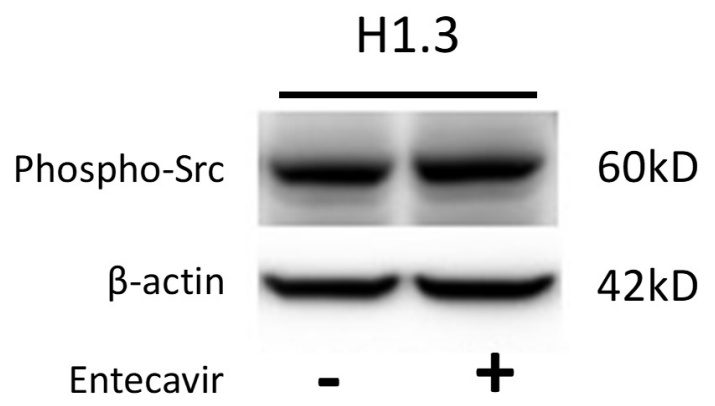

Figure 4: c-Src kinase activity in HBV-replicating hepatoma cells. (a) Total protein levels of c-Src kinase and its tyrosine 416 phosphorylated activated form (Tyr416) as well as HBV core protein were subjected to Western blot analysis in parental (-) compared to HBV-replicating (H1.3 + H1.3x-) HepG2 cells. (b) Total protein levels of the c-Src tyrosine 416 phosphorylated activated form (Tyr416) were subjected to Western blot analysis in HBV-replicating HepG2H1.3 cells either treated with the reverse transcriptase inhibitor Entecavir $(+)$ or not (-). 
a

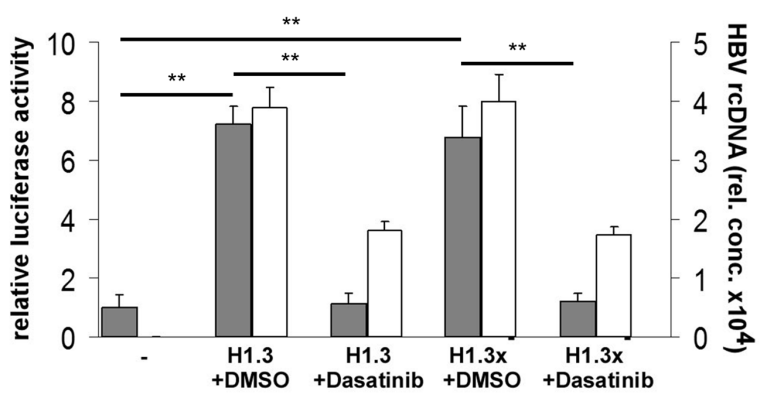

b
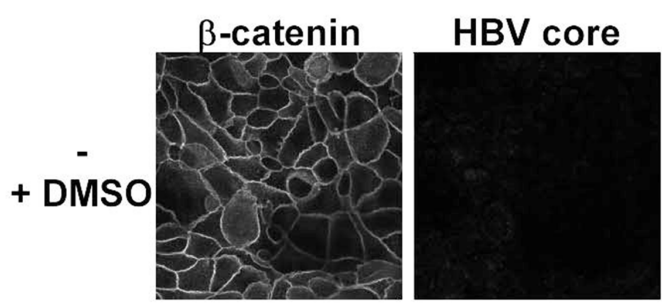

nuclei
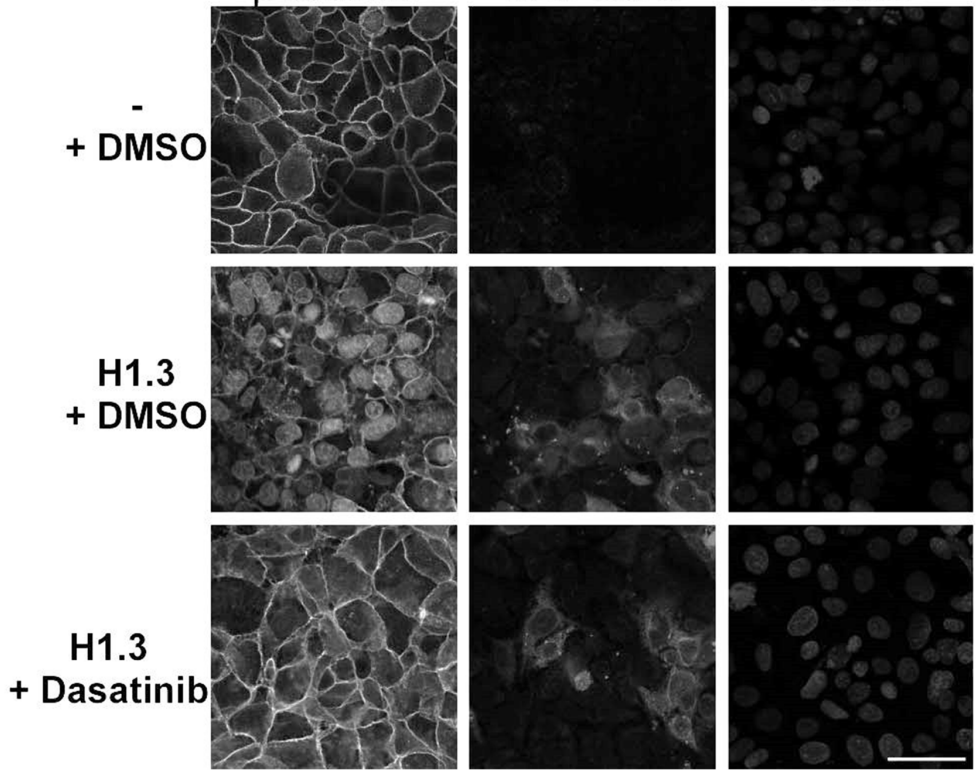

C
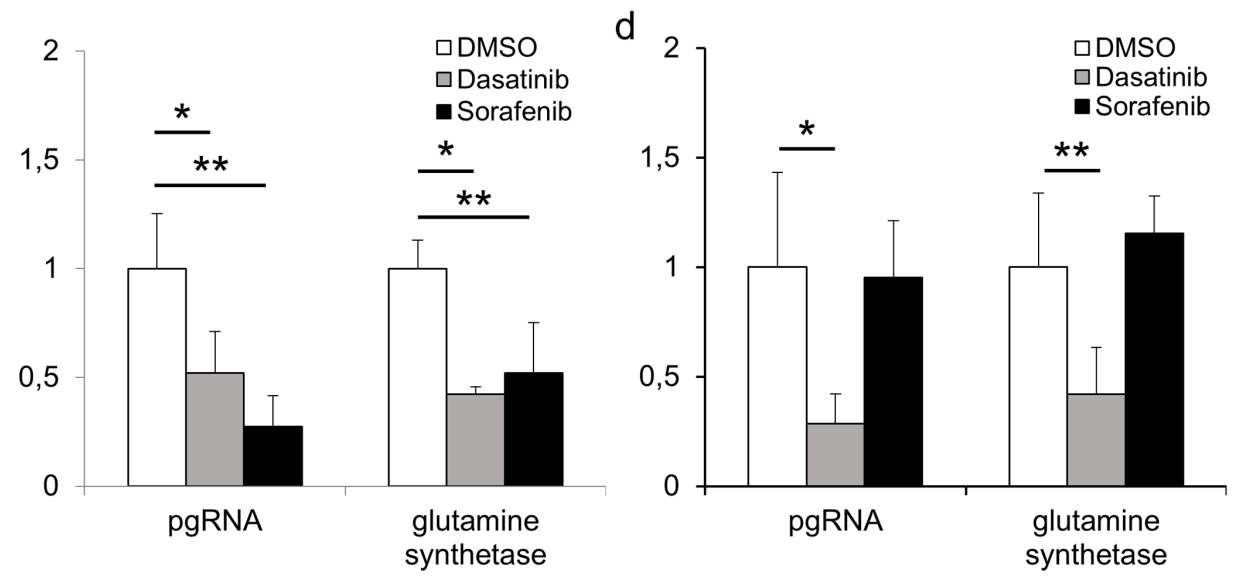

Figure 5: Tcf/LEF dependent $\beta$-catenin-signalling and target gene expression in hepatoma cells. (a) Relative luciferase activity indicates the level of Tcf/LEF dependent $\beta$-catenin-signalling (grey bars) in parental (-), H1.3x and H1.3 $\mathrm{x}^{-}$transfected Huh7 cells either treated with Dasatinib or DMSO. The ratio in parental cells was set to 1 . Active viral replication was determined by measuring HBV rcDNA (white bars) levels in supernatants of HBV-producing cells. The assays were performed in independent triplicates, means + SD are shown. ${ }^{* * *} \mathrm{p}<0.01$ vs parental cells and HBV replicating cells respectively, t-test. (b) Immunofluorescence staining of $\beta$-catenin in parental (-) and HBV-producing H1.3 Huh7 cells either treated with Dasatinib or DMSO. Co-staining of HBV core protein and nuclei. Scale bar indicates $40 \mu \mathrm{m}$. pgRNA and $\beta$-catenin-signalling dependent target gene mRNA were quantified by real-time PCR in (c) HBV infected HepG2-NTCP and (d) HBV infected Huh7.5-NTCP cells treated either with Dasatinib (grey bars) or Sorafenib (black bars) relative to DMSO treated HBV infected cells (white bars, ratios in DMSO treated cells were set to 1). Normalized expression ratios were relative to housekeeping gene GAPDH. The assays were performed in independent sixplicates, means $+\mathrm{SD}$ are shown. ${ }^{*} \mathrm{p}<0.05 ;{ }^{* *} \mathrm{p}<0.01$ vs DMSO treated HBV infected cells, t-test. 
Table 1: Staging and grading of human hepatocellular carcinoma samples

\begin{tabular}{lcccc}
\hline $\begin{array}{l}\text { Patient } \\
\text { number }\end{array}$ & $\begin{array}{c}\text { Serum HBsAg/ } \\
\text { antiHBc }\end{array}$ & $\begin{array}{c}\text { Tumor staging and } \\
\text { grading }\end{array}$ & $\begin{array}{c}\text { Peritumor, fibrosis } \\
\text { stage }\end{array}$ & $\begin{array}{c}\text { Peritumor } \\
\text { inflammation grade }\end{array}$ \\
\hline 1 & + & pT3 N0 Mx G2 R0 & 3 & 3 \\
2 & + & pT3 N0 Mx G3 R0 & 4 & 1 \\
3 & + & pT1 N0 Mx G2 R0 & $2-3$ & 2 \\
4 & + & pT1 N0 Mx G1 R0 & 4 & 2 \\
\hline
\end{tabular}

[45]. In our study, E-cadherin protein levels did not correlate with HBV replication - neither in hepatoma cells nor in liver tissue of HBV-infected patients. In chronically HBV-infected patients, E-cadherin levels were rather heterogeneous and showed a high inter-individual variation - not only in tumor but also in non-tumor tissue. Nevertheless, even though overall levels were not affected by HBV, we did observe a strong effect of HBV replication on E-cadherin localization with reduced cell surface expression and a more punctate cytoplasmic localization, suggesting increased internalization of E-cadherin. Alternatively, HBV may also reduce efficient transport to the cell surface. A previous study showed that phosphorylation of the cytoplasmic domain of E-cadherin by Src results in increased internalization into endosomes, which are then either degraded in the lysosome or recycled back to the cell surface [46]. Src also phosphorylates $\beta$-catenin at specific tyrosine residues, particularly at Y142 and Y654, which reduces its affinity for $\alpha$-catenin and E-cadherin, respectively [47, 48], thus promoting disassembly of the cadherin complex. As overexpression of E-cadherin sequesters $\beta$-catenin thus reducing its nuclear signalling activity [49-51], HBV induced disassembly of the junctions through Src may induce stabilization of $\beta$-catenin [52], and subsequent increased transcriptional activity. Moreover, HBV dependent activation of Src also suppresses glycogen synthase kinase 3 (GSK3) activity, the central kinase that targets $\beta$-catenin for proteosomal degradation, hence more directly stabilizing $\beta$-catenin.

In our experiments, HBV increased c-Src activity in HepG2 cells and specific inhibition of Src activity strongly reduced viral pgRNA transcription and replication, showing a bidirectional activation. This is in line with previous studies reporting that Src promotes reverse transcription as well as HBV-DNA replication $[4,5,53]$. However, in contrast to what was suggested previously [5], c-Src activation did not require HBx.

Previous studies showed that overexpression of HBx either disrupts adherens junctions [16] or induces epithelial-mesenchymal transition [54, 55] through Src activation or increases Wnt-dependent $\beta$-cateninsignalling [17, 56, 57]. Although overexpression of HBx is apparently able to induce these effects, in our study expression of $\mathrm{HBx}$ at moderate levels under its endogenous promoter did not do so. Importantly, deletion of HBx also did not affect the ability of HBV to induce c-Src, translocate E-cadherin or increase $\beta$-cateninsignalling. HBV (even without $\mathrm{HBx}$ ) was sufficient to enhance constitutive active $\beta$-catenin-signalling in HepG2 cells carrying a mutant $\beta$-catenin and, more importantly, to induce $\beta$-catenin-signalling in Huh7 cells that are wildtype for $\beta$-catenin.

Over the last years there has been an increasing interest in identifying new compounds that modify signalling pathways in HCC. It has been shown that antagonists of Tcf4/beta-catenin complex inhibit the growth of HCC cells in vitro and in vivo [58] highlighting the important role of the Wnt/ $\beta$-catenin-signalling in HCC $[59,60]$. In addition, overexpression of $\mathrm{Src}$ in association with reduced expression of a negative regulator of Src, the C-terminal Src kinase, has been observed [61, 62] and activation of the Src family of tyrosine kinases has been linked to adherens junction disassembly, increased $\beta$-catenin-signalling and cancer progression $[63,64]$.

These data as well as the results from our study indicate that targeting Src kinase might be a promising and specific therapeutic strategy against HBV-associated HCC. So far, only the multi-kinase inhibitor Sorafenib is approved for treatment of advanced HCC. In our study Sorafenib and Dasatinib were comparably effective in suppressing HBV replication and the expression of Tcf/ LEF dependent $\beta$-catenin-signalling target gene GS in HBV-infected HepG2-NTCP cells, that express a mutant, stabilized $\beta$-catenin. Interestingly, in $\mathrm{HBV}$ infected Huh7.5-NTCP cells, which express wildtype $\beta$-catenin, and therefore represent an important subgroup of HCCs, only Dasatinib treatment showed an effect. Thus, Dasatinib, which has already received clinical approval by American and European authorities for treatment of leukemia, may be an interesting treatment option for HBVdependent HCC.

Taken together, we have shown that HBV induces Src kinase dependent $\beta$-catenin-signalling and disassembly of adherens junctions, which interestingly does not require the viral transactivator HBx. Importantly, these HBV-dependent processes can be modified by the tyrosine kinase inhibitor Dasatinib. Our results provide new insights into HBV-host cell interaction and help 
to understand the molecular basis of HBV-associated carcinogenesis while also providing potentially novel therapeutic approaches against HBV.

\section{MATERIALS AND METHODS}

\section{Cell culture, transfection/infection, reporter assay and drugs}

Hepatoma cell lines HepG2, Huh7 and Huh7.5 were cultivated as described [38]. HepG2-H1.3 (clone2) and HepG2-H1.3x- (clone6) cells were generated by stable transfection with plasmids $\mathrm{pTH} 1.3 \mathrm{x}^{+/-}$(Supplementary Table 1). Cells were plated onto collagen-coated dishes and at $80-90 \%$ confluency maintained in WilliamsE/ DMEM 1:1 containing $1 \%$ fetal calf serum $[38,65]$.

Huh7 cells were transiently transfected with pTH1.3 $\mathrm{x}^{+/}$using Fugene 6 Transfection Reagent (Roche Diagnostics $\mathrm{GmbH}$, Mannheim, Germany).

HepG2-NTCP and Huh7.5-NTCP cells were cultivated and infected with HBV as described [66]. The multiplicity of infection (MOI) was 150 enveloped, DNAcontaining HBV virions per cell expected to result in a $30-40 \%$ infection rate in $\mathrm{HepG} 2$ cells.

To determine $\beta$-catenin-signalling activity, reporter plasmids were cotransfected (Supplementary Table 1). Three days after transfection, luciferase signals were measured and relative luciferase activity was determined as described $[67,68]$.

Dasatinib (Bristol-Myers Squibb, New York, NY, USA) and Sorafenib (LC Laboratories, Woburn, MA, USA) were diluted in DMSO and used for cell treatment (concentrations 2, $5 \mu \mathrm{g} \mathrm{ml}-1$ and 1, $25 \mu \mathrm{g} \mathrm{ml}-1$ respectively). Drug treatment was started one day post infection with HBV. Medium and drug substances were changed every two days.

Entecavir (Bristol-Myers Squibb, Uxbridge, UK) was reconstituted in water and used for cell treatment at a final concentration of $5 \mu \mathrm{M}$. Drug treatment was started 1 day after cell seeding when they reached $95-100 \%$ confluence. Medium and drug substances were changed every 3 days. Cells were harvested at day 7 .

Hepatitis $\mathrm{B}$ e antigen ( $\mathrm{HBe} \mathrm{Ag}$ ) was determined by a commercial assay (Axsym ${ }^{\mathrm{TM}}$, Abbott Diagnostics, Wiesbaden, Germany). The HBeAg concentration in $\mathrm{ng} / \mathrm{ml}$ was calculated using an International Standard for Hepatitis B Virus e Antigen from the Paul-EhrlichInstitut.

\section{Human liver tissue}

Snap frozen human HCC and non-tumor (peritumor) HBV-infected liver tissue samples (pat1-pat4) were selected from the tissue bank of the Institute of Pathology, University Hospital Cologne, established after informed consent of patients. Selection criteria were: active HBV infection (seropositivity for HBsAg and anti-HBc and/ or detectable HBV viremia), absence of other obvious cause for HCC (e.g. hepatitis C virus (HCV) infection, hematochromatosis), absence of human immunodeficiency virus (HIV) infection, and no serological evidence for acute infection with or reactivation of cytomegalovirus (CMV) or Epstein-Barr virus (EBV) infection. Tumors were graded according to the American Joint Commission on Cancer (Table 1). Non-tumor/HBV-negative liver tissue samples were obtained from human liver grafts (HBV, HCV, HIV negative) not suited for transplantation (pat5-pat8). The use of human tissue was approved by the local ethics committee and was in accordance with ethical standards as formulated in the Helsinki declaration.

\section{Real-time PCR}

One $\mu \mathrm{g}$ of total RNA extracted from HepG2 and Huh7.5 cells using total RNA extraction kit (Qiagen, Hilden, Germany) was transcribed into cDNA after DNase digestion using SuperScript II Reverse Transcriptase (Invitrogen, Carlsbad, USA). HBV pgRNA was detected as described [69]. For gene expression analysis, appropriate exon-exon spanning primer pairs were selected (Supplementary Table 2). To distinguish HBV-genomic-DNA from HBV-plasmid-DNA used for transfections, rcDNA specific primers $\mathrm{HBV} 3054 \mathrm{fw}$ 5'-ACTAGGAGGCTGTAGGCATA-3', HBV132rev 5'-AGACTCTAAGGCTTCCCG-3' were designed. Realtime PCRs were performed using the LightCycler ${ }^{\mathrm{TM}}$ system and normalized to a dilution series of calibrator cDNA using the Relative Quantification Software (both Roche Diagnostics) as described [69].

\section{Protein expression analysis}

Total proteins from cells and liver tissue were isolated using SDS lysis buffer $(15 \mathrm{mM}$ Tris/ $\mathrm{HCl}, \mathrm{pH}$ $6.8,2.5 \%$ glycerol, $0.5 \%$ SDS, $1 \mathrm{mM}$ EDTA with protease complete cocktail). Equal amounts of protein $(10-20 \mu \mathrm{g})$ were separated by 7.5 to $12.5 \%$ SDS-PAGE, transferred onto nitrocellulose membranes, stained with appropriate primary (Supplementary Table 3 ) and secondary antibodies (Sigma, Deisenhofen, Germany) and visualized by ECL Western Blot Detection Reagent (Amersham Bioscience, Buckinghamshire, England).

Cell surface proteins were biotinylated using a biotinylation kit (Pierce, Rockford, IL, USA), precipitated using streptavidin coupled agarose beads and analyzed by Western blot.

For immunofluorescence analysis, cells were fixed with $100 \%$ ice-cold methanol and stained with appropriate primary (Supplementary Table 3 ) and secondary antibodies (Alexa Fluor TM 488 or 594 conjugate (Molecular Probes, Eugene, OR, USA)). Nuclei were stained with Diamino-2phenylindol (DAPI). Fluorescence images were acquired 
using confocal microscope FluoView1000 (Olympus, Hamburg, Germany).

\section{Statistical analysis}

All data were expressed as means $\pm \mathrm{SD}$ (for number of replicates see figure legends). Data were tested for normality as well as equal variance and analyzed using a two-tailed $t$ test for equal or unequal variance, as appropriate. $p$ values $<0.05$ were considered statistically significant.

\section{Abbreviations}

HBV: hepatitis B virus; HCC: hepatocellular carcinoma; HBx: HBV X protein; EMT: mesenchymal transition; HBeAg: hepatitis $\mathrm{B}$ e antigen; pgRNA: pregenomic RNA; ALAS: aminolevulinate synthase; GS: glutamine synthetase; NTCP: sodium taurocholate cotransporting polypeptide.

\section{Author contributions}

G.O.: collection and assembly of data, data analysis and interpretation, manuscript writing. M.Q., C.N.: conception and design, collection and assembly of data, data analysis and interpretation. R.B., S.A., C.K., MvK, K.Z., M.O., M.R.: collection and assembly of data. U.P.: conception and design, data analysis and interpretation, manuscript writing. All authors reviewed and approved the final version of the manuscript.

\section{ACKNOWLEDGMENTS}

We thank Margarethe Krzyk, Annika Schmitz and Raindy Tedjokusumo for technical assistance and HansPeter Dienes for establishing the HepNet biobank.

\section{CONFLICTS OF INTEREST}

The authors declare no conflicts of interest.

\section{FUNDING}

This project was supported by the SFB829/A1 and NI685-2/1, NI685-6/1 as well as Krebshilfe to CN, by the Koeln Fortune Program (stipend) to GO and by the EU via the Hepcar consortium within the Horizon 2020 program to UP.

\section{REFERENCES}

1. Akinyemiju T, Abera S, Ahmed M, Alam N, Alemayohu MA, Allen C, Al-Raddadi R, Alvis-Guzman N, Amoako Y, Artaman A, Ayele TA, Barac A, Bensenor I, et al, and Global Burden of Disease Liver Cancer Collaboration.
The Burden of Primary Liver Cancer and Underlying Etiologies From 1990 to 2015 at the Global, Regional, and National Level: Results From the Global Burden of Disease Study 2015. JAMA Oncol. 2017; 3:1683-91. https://doi. org/10.1001/jamaoncol.2017.3055.

2. Petrick JL, Braunlin M, Laversanne M, Valery PC, Bray F, McGlynn KA. International trends in liver cancer incidence, overall and by histologic subtype, 1978-2007. Int J Cancer. 2016; 139:1534-45. https://doi.org/10.1002/ijc.30211.

3. Ringelhan M, McKeating JA, Protzer U. Viral hepatitis and liver cancer. Philos Trans R Soc Lond B Biol Sci. 2017; 372:20160274. https://doi.org/10.1098/rstb.2016.0274

4. Klein NP, Bouchard MJ, Wang LH, Kobarg C, Schneider RJ. Src kinases involved in hepatitis B virus replication. EMBO J. 1999; 18:5019-27. https://doi.org/10.1093/ emboj/18.18.5019.

5. Klein NP, Schneider RJ. Activation of Src family kinases by hepatitis B virus HBx protein and coupled signaling to Ras. Mol Cell Biol. 1997; 17:6427-36. https://doi.org/10.1128/ MCB.17.11.6427.

6. Cougot D, Neuveut C, Buendia MA. HBV induced carcinogenesis. J Clin Virol. 2005; 34:S75-8. https://doi. org/10.1128/MCB.17.11.6427.

7. Lupberger J, Hildt E. Hepatitis B virus-induced oncogenesis. World J Gastroenterol. 2007; 13:74-81. https:// doi.org/10.3748/wjg.v13.i1.74.

8. Mason WS, Gill US, Litwin S, Zhou Y, Peri S, Pop O, Hong ML, Naik S, Quaglia A, Bertoletti A, Kennedy PT. HBV DNA Integration and Clonal Hepatocyte Expansion in Chronic Hepatitis B Patients Considered Immune Tolerant. Gas troenterology. 2016; 151:986-98.e4. https:// doi.org/10.1053/j.gastro.2016.07.012

9. Nakamoto Y, Guidotti LG, Kuhlen CV, Fowler P, Chisari FV. Immune pathogenesis of hepatocellular carcinoma. J Exp Med. 1998; 188:341-50. https://doi.org/10.1084/ jem.188.2.341.

10. Ringelhan M, O'Connor T, Protzer U, Heikenwalder M. The direct and indirect roles of $\mathrm{HBV}$ in liver cancer: prospective markers for HCC screening and potential therapeutic targets. J Pathol. 2015; 235:355-67. https://doi.org/10.1002/ path.4434.

11. Hsieh YH, Su IJ, Wang HC, Chang WW, Lei HY, Lai MD, Chang WT, Huang W. Pre-S mutant surface antigens in chronic hepatitis B virus infection induce oxidative stress and DNA damage. Carcinogenesis. 2004; 25:2023-32. https://doi.org/10.1093/carcin/bgh207.

12. Wang HC, Chang WT, Chang WW, Wu HC, Huang W, Lei HY, Lai MD, Fausto N, Su IJ. Hepatitis B virus pre-S2 mutant upregulates cyclin A expression and induces nodular proliferation of hepatocytes. Hepatology. 2005; 41:761-70. https://doi.org/10.1002/hep.20615.

13. Bouchard MJ, Wang L, Schneider RJ. Activation of focal adhesion kinase by hepatitis B virus HBx protein: multiple functions in viral replication. J Virol. 2006; 80:4406-14. https://doi.org/10.1128/JVI.80.9.4406-4414.2006. 
14. Bouchard MJ, Wang LH, Schneider RJ. Calcium signaling by $\mathrm{HBx}$ protein in hepatitis B virus DNA replication. Science. 2001; 294:2376-8. https://doi.org/10.1126/ science.294.5550.2376.

15. Lara-Pezzi E, Serrador JM, Montoya MC, Zamora D, Yanez-Mo M, Carretero M, Furthmayr H, Sanchez-Madrid F, Lopez-Cabrera M. The hepatitis B virus X protein (HBx) induces a migratory phenotype in a CD44-dependent manner: possible role of $\mathrm{HBx}$ in invasion and metastasis. Hepatology. 2001; 33:1270-81. https://doi.org/10.1053/ jhep.2001.1270.

16. Lara-Pezzi E, Roche S, Andrisani OM, Sanchez-Madrid F, Lopez-Cabrera M. The hepatitis B virus HBx protein induces adherens junction disruption in a src-dependent manner. Oncogene. 2001; 20:3323-31. https://doi. org/10.1038/sj.onc. 1204451.

17. Cha MY, Kim CM, Park YM, Ryu WS. Hepatitis B virus X protein is essential for the activation of $\mathrm{Wnt} /$ beta-catenin signaling in hepatoma cells. Hepatology. 2004; 39:1683-93. https://doi.org/10.1002/hep.20245.

18. Decorsiere A, Mueller $\mathrm{H}$, van Breugel PC, Abdul F, Gerossier L, Beran RK, Livingston CM, Niu C, Fletcher SP, Hantz O, Strubin M. Hepatitis B virus X protein identifies the Smc5/6 complex as a host restriction factor. Nature. 2016; 531:386-9. https://doi.org/10.1038/nature17170.

19. Cadigan KM, Nusse R. Wnt signaling: a common theme in animal development. Genes Dev. 1997; 11:3286-305. https://doi.org/10.1101/gad.11.24.3286.

20. Clevers H. Wnt/beta-catenin signaling in development and disease. Cell. 2006; 127:469-80. https://doi.org/10.1016/j. cell.2006.10.018.

21. Behrens J, von Kries JP, Kuhl M, Bruhn L, Wedlich D, Grosschedl R, Birchmeier W. Functional interaction of betacatenin with the transcription factor LEF-1. Nature. 1996; 382:638-42. https://doi.org/10.1038/382638a0.

22. Molenaar $M$, van de Wetering $M$, Oosterwegel $M$, Peterson-Maduro J, Godsave S, Korinek V, Roose J, Destree O, Clevers H. XTcf-3 transcription factor mediates beta-catenin-induced axis formation in Xenopus embryos. Cell. 1996; 86:391-9. https://doi.org/10.1016/ S0092-8674(00)80112-9.

23. Cadoret A, Ovejero C, Terris B, Souil E, Levy L, Lamers WH, Kitajewski J, Kahn A, Perret C. New targets of betacatenin signaling in the liver are involved in the glutamine metabolism. Oncogene. 2002; 21:8293-301. https://doi. org/10.1038/sj.onc. 1206118.

24. de La Coste A, Romagnolo B, Billuart P, Renard CA, Buendia MA, Soubrane O, Fabre M, Chelly J, Beldjord C, Kahn A, Perret C. Somatic mutations of the beta-catenin gene are frequent in mouse and human hepatocellular carcinomas. Proc Natl Acad Sci U S A. 1998; 95:8847-51. https://doi.org/10.1073/pnas.95.15.8847.

25. Loeppen S, Schneider D, Gaunitz F, Gebhardt R, Kurek R, Buchmann A, Schwarz M. Overexpression of glutamine synthetase is associated with beta-cateninmutations in mouse liver tumors during promotion of hepatocarcinogenesis by phenobarbital. Cancer Res. 2002; 62:5685-8.

26. Morin PJ. beta-catenin signaling and cancer. Bioessays. 1999; 21:1021-30. https://doi.org/10.1002/(SICI)15211878(199912)22:1<1021::AID-BIES6>3.0.CO;2-P.

27. Lee HC, Kim M, Wands JR. Wnt/Frizzled signaling in hepatocellular carcinoma. Front Biosci. 2006; 11:1901-15. https://doi.org/10.2741/1933.

28. Giles RH, van Es JH, Clevers H. Caught up in a Wnt storm: Wnt signaling in cancer. Biochim Biophys Acta. 2003; 1653:1-24. https://doi.org/10.1016/ S0304-419X(03)00005-2.

29. Colnot S, Decaens T, Niwa-Kawakita M, Godard C, Hamard G, Kahn A, Giovannini M, Perret C. Liver-targeted disruption of Apc in mice activates beta-catenin signaling and leads to hepatocellular carcinomas. Proc Natl Acad Sci U S A. 2004; 101:17216-21. https://doi.org/10.1073/ pnas.0404761101.

30. Niessen CM, Gottardi CJ. Molecular components of the adherens junction. Biochim Biophys Acta. 2008; 1778:56271. https://doi.org/10.1016/j.bbamem.2007.12.015.

31. Hugo H, Ackland ML, Blick T, Lawrence MG, Clements JA, Williams ED, Thompson EW. Epithelial-mesenchymal and mesenchymal-epithelial transitions in carcinoma progression. J Cell Physiol. 2007; 213:374-83. https://doi. org/10.1002/jcp.21223.

32. Thompson EW, Williams ED. EMT and MET in carcinoma - clinical observations, regulatory pathways and new models. Clin Exp Metastasis. 2008; 25:591-2. https:// doi.org/10.1007/s10585-008-9189-8.

33. Nelson WJ, Nusse R. Convergence of Wnt, beta-catenin, and cadherin pathways. Science. 2004; 303:1483-7. https:// doi.org/10.1126/science.1094291.

34. Derksen PW, Liu X, Saridin F, van der Gulden H, Zevenhoven J, Evers B, van Beijnum JR, Griffioen AW, Vink J, Krimpenfort P, Peterse JL, Cardiff RD, Berns A, et al. Somatic inactivation of E-cadherin and p53 in mice leads to metastatic lobular mammary carcinoma through induction of anoikis resistance and angiogenesis. Cancer Cell. 2006; 10:437-49. https://doi.org/10.1016/j. ccr.2006.09.013.

35. Wei Y, Van Nhieu JT, Prigent S, Srivatanakul P, Tiollais $\mathrm{P}$, Buendia MA. Altered expression of E-cadherin in hepatocellular carcinoma: correlations with genetic alterations, beta-catenin expression, and clinical features. Hepatology. 2002; 36:692-701. https://doi.org/10.1053/ jhep.2002.35342.

36. Kanai Y, Ushijima S, Hui AM, Ochiai A, Tsuda H, Sakamoto M, Hirohashi S. The E-cadherin gene is silenced by $\mathrm{CpG}$ methylation in human hepatocellular carcinomas. Int J Cancer. 1997; 71:355-9. https://doi.org/10.1002/(SICI) 1097-0215(19970502)71:3<355::AID-IJC8>3.0.CO;2-X. 
37. Calvisi DF, Ladu S, Conner EA, Factor VM, Thorgeirsson SS. Disregulation of E-cadherin in transgenic mouse models of liver cancer. Lab Invest. 2004; 84:1137-47. https://doi. org/10.1038/labinvest.3700147.

38. Quasdorff M, Hosel M, Odenthal M, Zedler U, Bohne F, Gripon P, Dienes HP, Drebber U, Stippel D, Goeser T, Protzer U. A concerted action of HNF4alpha and HNF1alpha links hepatitis B virus replication to hepatocyte differentiation. Cell Microbiol. 2008; 10:1478-90. https:// doi.org/10.1111/j.1462-5822.2008.01141.x.

39. Glebe D, Berting A, Broehl S, Naumann H, Schuster R, Fiedler N, Tolle TK, Nitsche S, Seifer M, Gerlich WH, Schaefer S. Optimised conditions for the production of hepatitis B virus from cell culture. Intervirology. 2001; 44:370-8. https://doi.org/10.1159/000050074.

40. Lombardo LJ, Lee FY, Chen P, Norris D, Barrish JC, Behnia K, Castaneda S, Cornelius LA, Das J, Doweyko AM, Fairchild C, Hunt JT, Inigo I, et al. Discovery of N-(2-chloro-6-methyl-phenyl)-2-(6-(4(2-hydroxyethyl)-piperazin-1-yl)-2-methylpyrimidin-4ylamino)thiazole-5-carboxamide (BMS-354825), a dual Src/Abl kinase inhibitor with potent antitumor activity in preclinical assays. J Med Chem. 2004; 47:6658-61. https://doi.org/10.1021/jm049486a.

41. Burgess MR, Skaggs BJ, Shah NP, Lee FY, Sawyers CL. Comparative analysis of two clinically active BCR-ABL kinase inhibitors reveals the role of conformation-specific binding in resistance. Proc Natl Acad Sci U S A. 2005; 102:3395-400. https://doi.org/10.1073/pnas.0409770102.

42. Verrier ER, Colpitts CC, Schuster C, Zeisel MB, Baumert TF. Cell Culture Models for the Investigation of Hepatitis B and D Virus Infection. Viruses. 2016; 8:E261. https://doi. org/10.3390/v8090261.

43. Liu L, Cao Y, Chen C, Zhang X, McNabola A, Wilkie D, Wilhelm S, Lynch M, Carter C. Sorafenib blocks the RAF/ MEK/ERK pathway, inhibits tumor angiogenesis, and induces tumor cell apoptosis in hepatocellular carcinoma model PLC/PRF/5. Cancer Res. 2006; 66:11851-8. https:// doi.org/10.1158/0008-5472.CAN-06-1377.

44. Llovet JM, Ricci S, Mazzaferro V, Hilgard P, Gane E, Blanc JF, de Oliveira AC, Santoro A, Raoul JL, Forner A, Schwartz M, Porta C, Zeuzem S, et al. Sorafenib in advanced hepatocellular carcinoma. N Engl J Med. 2008; 359:378-90. https://doi.org/10.1056/NEJMoa0708857.

45. Liu J, Lian Z, Han S, Waye MM, Wang H, Wu MC, Wu K, Ding J, Arbuthnot P, Kew M, Fan D, Feitelson MA. Downregulation of E-cadherin by hepatitis $\mathrm{B}$ virus $\mathrm{X}$ antigen in hepatocellullar carcinoma. Oncogene. 2006; 25:1008-17. https://doi.org/10.1038/sj.onc.1209138.

46. Palacios F, Tushir JS, Fujita Y, D'Souza-Schorey C. Lysosomal targeting of E-cadherin: a unique mechanism for the down-regulation of cell-cell adhesion during epithelial to mesenchymal transitions. Mol Cell Biol. 2005; 25:389402. https://doi.org/10.1128/MCB.25.1.389-402.2005.
47. Lilien J, Balsamo J. The regulation of cadherin-mediated adhesion by tyrosine phosphorylation/dephosphorylation of beta-catenin. Curr Opin Cell Biol. 2005; 17:459-65. https:// doi.org/10.1016/j.ceb.2005.08.009.

48. Piedra J, Martinez D, Castano J, Miravet S, Dunach M, de Herreros AG. Regulation of beta-catenin structure and activity by tyrosine phosphorylation. J Biol Chem. 2001; 276:20436-43. https://doi.org/10.1074/jbc.M100194200.

49. Stockinger A, Eger A, Wolf J, Beug H, Foisner R. E-cadherin regulates cell growth by modulating proliferation-dependent beta-catenin transcriptional activity. J Cell Biol. 2001; 154:1185-96. https://doi.org/10.1083/ jcb.200104036.

50. Orsulic S, Huber O, Aberle H, Arnold S, Kemler R. E-cadherin binding prevents beta-catenin nuclear localization and beta-catenin/LEF-1-mediated transactivation. J Cell Sci. 1999; 112:1237-45.

51. Gottardi CJ, Wong E, Gumbiner BM. E-cadherin suppresses cellular transformation by inhibiting beta-catenin signaling in an adhesion-independent manner. J Cell Biol. 2001; 153:1049-60. https://doi.org/10.1083/jcb.153.5.1049.

52. Maher MT, Flozak AS, Stocker AM, Chenn A, Gottardi CJ. Activity of the beta-catenin phosphodestruction complex at cell-cell contacts is enhanced by cadherin-based adhesion. J Cell Biol. 2009; 186:219-28. https://doi.org/10.1083/ jcb.200811108.

53. Natoli G, Avantaggiati ML, Chirillo P, Puri PL, Ianni A, Balsano C, Levrero M. Ras- and Raf-dependent activation of c-jun transcriptional activity by the hepatitis $\mathrm{B}$ virus transactivator pX. Oncogene. 1994; 9:2837-43.

54. Yang SZ, Zhang LD, Zhang Y, Xiong Y, Zhang YJ, Li HL, Li XW, Dong JH. HBx protein induces EMT through c-Src activation in SMMC-7721 hepatoma cell line. Biochem Biophys Res Commun. 2009; 382:555-60. https://doi. org/10.1016/j.bbrc.2009.03.079.

55. Shin Kim S, Yeom S, Kwak J, Ahn HJ, Lib Jang K. Hepatitis $\mathrm{B}$ virus $\mathrm{X}$ protein induces epithelial-mesenchymal transition by repressing E-cadherin expression via upregulation of E12/E47. J Gen Virol. 2016; 97:134-43. https://doi. org/10.1099/jgv.0.000324.

56. Shen L, Zhang X, Hu D, Feng T, Li H, Lu Y, Huang J. Hepatitis B virus $\mathrm{X}(\mathrm{HBx})$ play an anti-apoptosis role in hepatic progenitor cells by activating Wnt/beta-catenin pathway. Mol Cell Biochem. 2013; 383:213-22. https://doi. org/10.1007/s11010-013-1769-5.

57. Hsieh A, Kim HS, Lim SO, Yu DY, Jung G. Hepatitis B viral $X$ protein interacts with tumor suppressor adenomatous polyposis coli to activate $\mathrm{Wnt} /$ beta-catenin signaling. Cancer Lett. 2011; 300:162-72. https://doi.org/10.1016/j. canlet.2010.09.018.

58. Wei W, Chua MS, Grepper S, So S. Small molecule antagonists of Tcf4/beta-catenin complex inhibit the growth of HCC cells in vitro and in vivo. Int J Cancer. 2010; 126:2426-36. https://doi.org/10.1002/ijc.24810. 
59. Vilchez V, Turcios L, Marti F, Gedaly R. Targeting Wnt/ beta-catenin pathway in hepatocellular carcinoma treatment. World J Gastroenterol. 2016; 22:823-32. https://doi. org/10.3748/wjg.v22.i2.823.

60. Thompson MD, Monga SP. WNT/beta-catenin signaling in liver health and disease. Hepatology. 2007; 45:1298-305. https://doi.org/10.1002/hep.21651.

61. Masaki T, Okada M, Shiratori Y, Rengifo W, Matsumoto K, Maeda S, Kato N, Kanai F, Komatsu Y, Nishioka M, Omata M. pp60c-src activation in hepatocellular carcinoma of humans and LEC rats. Hepatology. 1998; 27:1257-64. https://doi.org/10.1002/hep.510270511.

62. Masaki T, Okada M, Tokuda M, Shiratori Y, Hatase O, Shirai M, Nishioka M, Omata M. Reduced C-terminal Src kinase (Csk) activities in hepatocellular carcinoma. Hepatology. 1999; 29:379-84. https://doi.org/10.1002/ hep.510290239.

63. Irby RB, Yeatman TJ. Role of Src expression and activation in human cancer. Oncogene. 2000; 19:5636-42. https://doi. org/10.1038/sj.onc. 1203912.

64. Frame MC. Src in cancer: deregulation and consequences for cell behaviour. Biochim Biophys Acta. 2002; 1602:11430. https://doi.org/10.1016/S0304-419X(02)00040-9.

65. Protzer U, Seyfried S, Quasdorff M, Sass G, Svorcova M, Webb D, Bohne F, Hosel M, Schirmacher P, Tiegs G. Antiviral activity and hepatoprotection by heme oxygenase-1 in hepatitis $\mathrm{B}$ virus infection.
Gastroenterology. 2007; 133:1156-65. https://doi. org/10.1053/j.gastro.2007.07.021.

66. Ko C, Chakraborty A, Chou WM, Hasreiter J, Wettengel JM, Stadler D, Bester R, Asen T, Zhang K, Wisskirchen K, McKeating JA, Ryu WS, Protzer U. Hepatitis B virus (HBV) genome recycling and de novo secondary infection events maintain stable cccDNA levels. J Hepatol. 2018 Aug 21. https://doi.org/10.1016/j.jhep.2018.08.012. [Epub ahead of print].

67. Evans AJ, Russell RC, Roche O, Burry TN, Fish JE, Chow VW, Kim WY, Saravanan A, Maynard MA, Gervais ML, Sufan RI, Roberts AM, Wilson LA, et al. VHL promotes E2 box-dependent E-cadherin transcription by HIF-mediated regulation of SIP1 and snail. Mol Cell Biol. 2007; 27:15769. https://doi.org/10.1128/MCB.00892-06.

68. Korinek V, Barker N, Morin PJ, van Wichen D, de Weger R, Kinzler KW, Vogelstein B, Clevers H. Constitutive transcriptional activation by a beta-catenin-Tcf complex in APC-/- colon carcinoma. Science. 1997; 275:1784-7. https://doi.org/10.1126/science.275.5307.1784.

69. Untergasser A, Zedler U, Langenkamp A, Hosel M, Quasdorff M, Esser K, Dienes HP, Tappertzhofen B, Kolanus W, Protzer U. Dendritic cells take up viral antigens but do not support the early steps of hepatitis B virus infection. Hepatology. 2006; 43:539-47. https://doi. org/10.1002/hep. 21048 . 